SURAKARTA

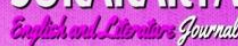

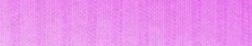

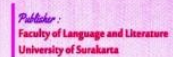

\section{SURAKARTA ENGLISH AND LITERATURE JOURNAL}

Vol 1 No.1 AUGUST 2018

Publisher Language and Literature Faculty, University of Surakarta

ISSN Print: 2621-9077 ISSN Online: 2621-9085

\title{
The Analysis of Implicature in the Presidential Election Campaign 2019 on Online Billboard Advertisement
}

\author{
Widyashanti Kunthara Anindita \\ Faculty of Language and Literature, University of Surakarta. wk.anindita@gmail.com
}

\begin{abstract}
This study aims to describe and explain 1) The implicatures on the utterances of 2019 Presidential election campaign on online billboard advertisements (2) The types of implicatures on the utterances of 2019 Presidential election campaign on online billboard advertisements (3) The function of those implicatures. The research method in this study is a qualitative approach that uses content analysis. This is intended to trace three formulation of problems related to the conversational implicature. Data is the utterances containing implicatures and data is taken from 2019 presidential election campaign ononline billboard advertisements. The results of the discussion showed that out of 11 online billboards, most speakers flouted Quality maxim as much as 6 online billboard advertisements and the speakers also flouted Quantity maxim as much as 3 online billboards advertisements. The rest, 1 online billboard advertisement includes the flouting of manner maxim and 1 online billboard advertisement includes the flouting of Relation maxim. The types of implicatures that occur are generalized implicatures and particularized implicatures. Implicature in this study has 2 functions, namely directive (asking, inviting and convincing) and commissive (promising).
\end{abstract}

Keywords: implicature, the flouting of maxim, utterance functions, presidential election campaign

\begin{abstract}
ABSTRAK
Penelitian ini bertujuan untuk mendeskripsikan dan menjelaskan 1) Implikatur yang terdapat pada tuturan kampanye pemilihan Presiden 2019 di iklan baliho online (2) Jenis implikatur yang terdapat pada tuturan kampanye pemilihan Presiden 2019 di iklan baliho online (3) Fungsi implikatur tersebut. Metode penelitian pada studi ini
\end{abstract}




\section{Vol 1, No.1 AUGUST 2018}

adalah pendekatan kualitatif yang menggunakan analisa konten. Hal ini dimaksudkan untuk menelusuri tiga rumusan masalah yang berkaitan dengan implikatur percakapan. Data berupa tuturan yang mengandung implikatur dan data diambil dari kampanye presiden 2019 di iklan baliho online. Hasil pembahasan menunjukkan bahwa dari 11 iklan baliho online, sebagian besar penutur melanggar maksim kualitas sebanyak 6 iklan baliho online dan maksim kuantitas sebanyak 3 iklan baliho online. Sisanya, 1 iklan baliho online termasuk pelanggaran maksim manner dan 1 iklan baliho online termasuk pelanggaran maksim relasi. Jenis implikatur yang muncul adalah implikatur umum dan implikatur khusus. Implikatur pada penelitian ini memiliki 2 fungsi yaitu direktif (meliputi meminta, mengajak dan meyakinkan) serta komisif (berjanji).

Kata kunci: Implikatur, pelanggaran maksim, fungsi tindak tutur, kampanye pemilihan Presiden

\section{INTRODUCTION}

According to Oxford dictionary, an advertisement is a notice or announcement in a public medium promoting a product, service, or event or publicizing a job vacancy(https://en.oxforddictionaries.com/definition/advertisement). Whileonline advertising is a marketing strategy that involves the use of the Internet as a medium to obtain website traffic and target and deliver marketing messages to the right customers (https://www.techopedia.com/definition/26362/online-advertising). The purpose of advertising is to inform the consumers about their product and convince customers that a company's services or products are the best, enhance the image of the company, point out and create a need for products or services, demonstrate new uses for established products, announce new products and programs, reinforce the salespeople's individual messages, draw customers to the business, and to hold existing customers (https://en.wikipedia.org/wiki/Advertising). The use of language in a presidential election campaign can be done in oral and written. One of the written languages is the utterances of 2019 presidential election campaign on Onlinebillboard advertisements. The writer took the 2019 presidential election campaign on online billboard advertisements where people can easily find those campaigns advertised in billboard from many online sources. The contents of the campaign are very interesting to observe because these activities show the form of language that is used in such a way as to influence or persuade readers to choose the presidential candidate based on the vision and mission stated on the online campaign advertisement.

Every utterance on the presidentialelection campaign has a specific purpose that may not be directly understood byreaders because of the context binding the utterances. Conversational implicature is an implicative proposition or statement, namely what might be interpreted, implied, or intended by speakers, which is different from what is said by speakers in a conversation (Grice 1975; Nugraheni 2011).Lakoff in Huda (2013:30) states when maxims are blatantly flouted give rise to GriceanImplicature.

\section{Surakarta English and Literature Journal}


Grice in Cutting (2013:57) distinguished two different sorts of implicature: conventional (generated)implicatureand conversational (particularized)implicature.Levinson in Cutting lists four words such as but, even, thereforeandyet. The word butcarries the implicature that what followsrun counter toexpectations - this sense of the word but always carries thisimplicature, regardless of the context in which it occurs (for instance 'Myfriends were poor, but honest', 'He is small, but perfectly formed', etc).Meanwhile, conversational implicature (particularized implicature)arises only in a particular context of utterance.For instance; 'Great, that's really great! That is made my Christmas!'. This sentence is not a praise sentence but ithas animplicature that is the speaker was furious because someone had just vomitedover him!.

This research will discuss implicature analysis in the presidential election campaign 2019on online billboard advertisements. Besides analyzing the implicature meaning, it is also important to analyze the speech act. According to Yule in Anindita (2009:18), actions performed via utterances are generally called 'Speech Act'such as apology, compliment, invitation, promise, request, etc. There are numerous speech acts in people's utterances and Searle (Anindita.2009:20) classifies them into five groups: 1) Assertive commits $s$ to the truth of the expressed proposition; eg.stating, suggesting, complaining, boasting, claiming, reporting; 2)Directive (Impositive) is intended to produce some effect through action by the hearer; eg.ordering, commanding, requesting, advising. On the other hand, some directives (such as invitation) are polite; 3)Commissive commits $s$ to some future action; eg.promising, vowing, offering; 4)Expressive has the function of expressing or making known, the speaker's psychological attitude towards a state of affairs which the illocution presupposes; eg.thanking, congratulating, pardoning, blaming, praising, condoling, etc; 5)Declaration is illocution whose succesful performance brings about the correspondence between the propositional content and reality; eg.resigning, dismissing, christening, naming, excommunicating, appointing, sentencing, etc.

The researcher chooses the analysis of implicature to help the wider community to understand the implicit meaning and its functions. Gunarwan (2007: 247; Handono: 2017) reveals that implicature is needed in utterance because it connects between expressions, meanings, speakers' meaning, and implications of utterances.

The researcher limits the data only to utterances that flout the principle of conversation, because this study deals with implicit meanings that can be calculated by flouting Grice's cooperative principle. The main objective of this study is to discover how utterance can go beyond its literal meaning by flouting the cooperative principles in the presidential election campaign 2019 on online billboard advertisement. There are three research problems being observed namely: (1) What are the implicatures that occur in the presidential election campaign 2019 on online billboard advertisement (2) What type of conversational implicature inthe presidential election campaign 2019 on online billboard advertisement (3) What is the function of the implicature.

\section{RESEARCH METHOD}

The method of this research is qualitative, with the research object is online advertising campaign for presidential candidates in 2019 by using pragmatic review. Research data are

\section{Surakarta English and Literature Journal}


advertising text in the form of words, phrases, clauses, sentences, or paragraphs that are supported by visual images such as colors, illustrations, and logos. The source data of this research was obtained from many online sources advertised in billboard.

Qualitative data is collected by observing and documentation methods. Observing to the use of language (Sudaryanto, 2015: 203) has a follow-up technique, namely note-taking technique. Taking notes the use of language contained in online documentation. In this documentation method, the researchertook pictures of online advertising campaigns for the presidential election in 2019.

Miles and Hubermanin Huda (2013: 12) reveal three current flows of data analysis, namely data reduction, data display, and conclusion drawing/verification. Data reduction is the process of selecting, focusing, simplifying, abstracting, and transforming data that exists in the real transcriptions. Data display is organized information including the final conclusion. Conclusion drawing is meant to state a temporal result of the study.

\section{FINDING AND DISCUSSION}

This chapter presents the research findings and discussion. In this chapter, the analysis of the data is in line with the formulated research questions. In Findings, there are three stages in analyzing the data, namely data reduction, data display, data analysis and conclusion drawing. However, the data analysis is written in separate way which then investigates the implicatures that raises as the result of flouted maxim, the types of conversational implicature and the function of implicature.

Since there are three stages of finding the result used in this study, the writer starts reducing some utterances that flout the cooperative principle sub-maxim which result conversational implicature. After that, the data are displayed using table. The whole data are finally analyzed based on the types of conversational implicature and their function within the utterances in the presidential election campaign 2019 on online billboard advertisements.

\section{DATA DESCRIPTION}

There are 53 utterances in phrases in 12 billboard advertisements of the 2019 presidential election campaign accessed on 20-23 February 2019. However, the writer reduced some utterances only into utterances that containing implicature or utterances that flout the Gricean maxim. The writer considers that since the utterance that does not flout the maxim of conversation means there will be no conversational implicature in it because conversational implicature can be calculated by flouting maxim of conversation. The writer found 122 wordsin 11 billboard advertisements containing conversational implicatures or utterance which is indicated to flout maxim of conversation. These utterances are displayed in the following Table 1 .

Table 1. Utterances that Flout the Conversational Maxim

\begin{tabular}{|c|c|c|c|c|}
\hline No & Utterances & Floutec & Maxim & Implicature \\
\hline & & $\begin{array}{ll}\mathrm{Ql} & \mathrm{Qt}\end{array}$ & $\begin{array}{ll}\mathrm{Mn} & \mathrm{R}\end{array}$ & \\
\hline 1 & $\begin{array}{l}\text { GolkarBersih,GolkarMenang,J } \\
\text { okowi } 2 \text { Periode }\end{array}$ & $\mathrm{V}$ & & $\begin{array}{l}\text { Golkar is a party that } \\
\text { always supports Jokowi } \\
\text { to become president }\end{array}$ \\
\hline
\end{tabular}


Golkar is clean, Golkar wins, Jokowi 2 Periodes

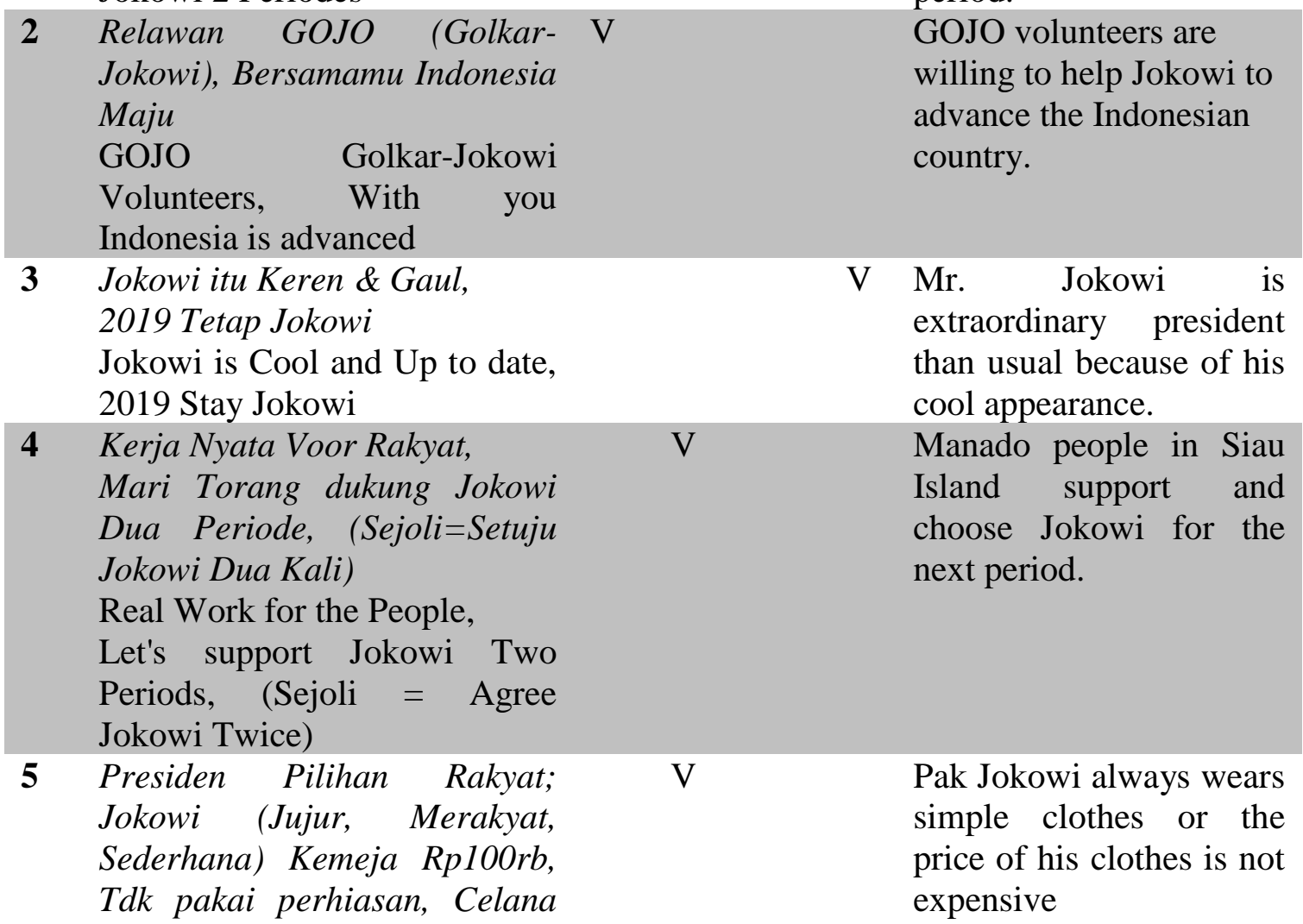

Rp110rb, Sepatu Rp160rb.

President of the People's

Choice; Jokowi (Honest,

Popular, Simple) Rp100.000

Shirt, No Jewelry, Pants

Rp110.000, Shoes Rp160.000

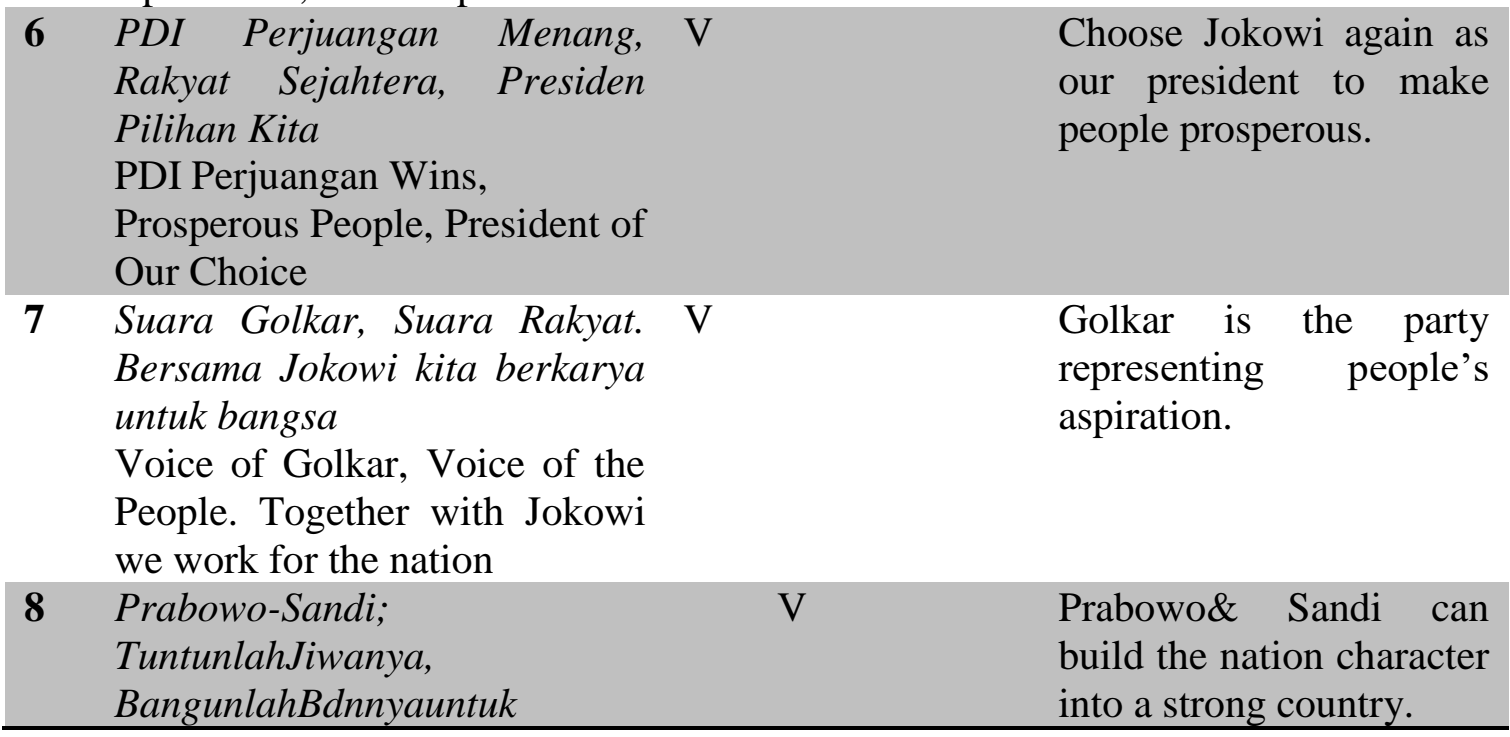


Vol.1, No.1 AUGUST 2018

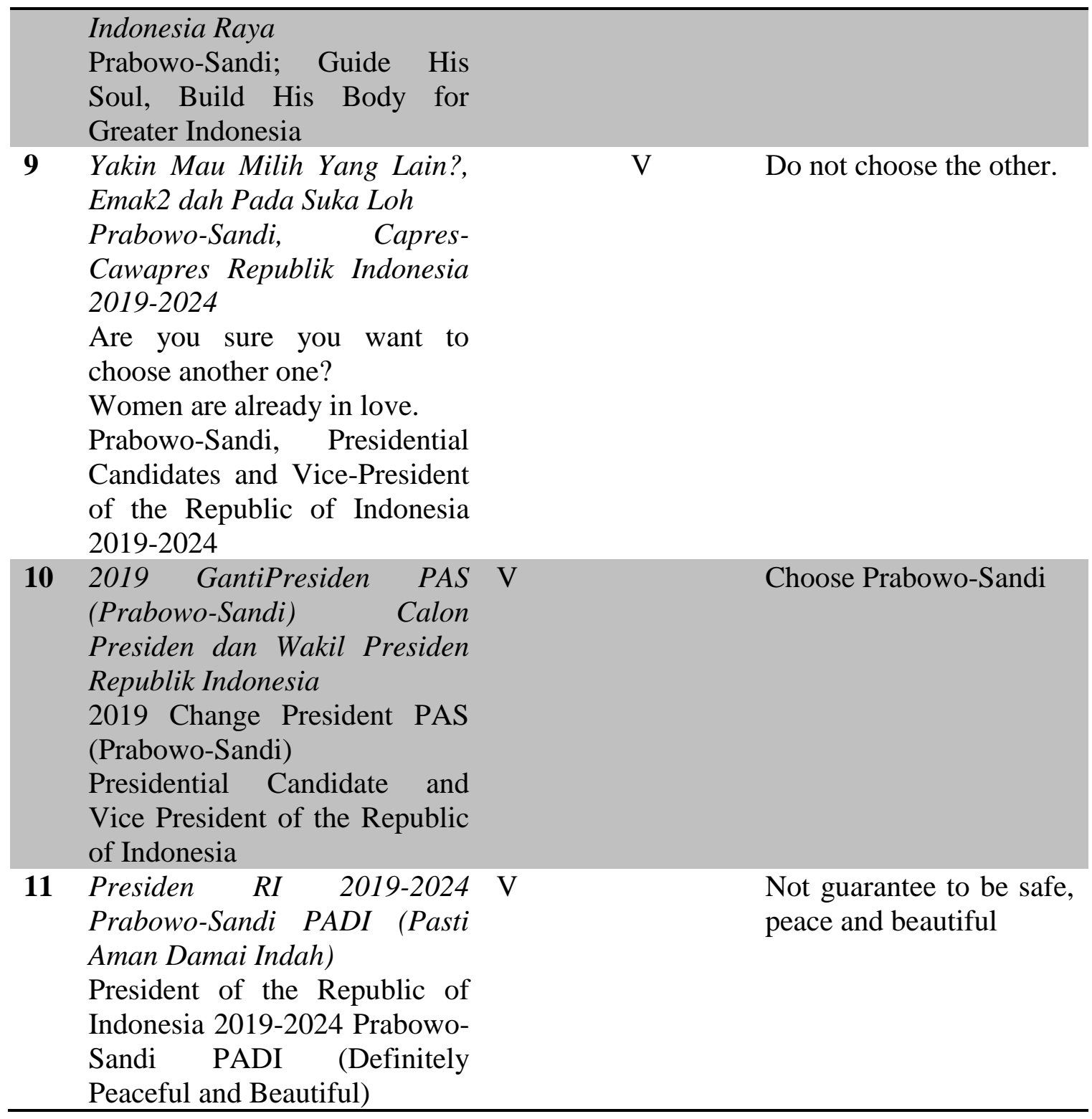

Note:

Q1 =Quality $\quad$ Mn=Manner

$\mathrm{Qt}=$ Quantity $\mathrm{Rl}=$ Relation

\section{RESULT OF ANALYSIS}

After presenting the data,it is necessary to analyze the conversational implicature within these utterances, the type of conversational implicature and the function of implicature. The complete explanation is elaborated in table 2 .

Table 2.Conversational Implicature Classification Based on Types of Conversational Implicature and the Function of Implicature

\begin{tabular}{llllll}
\hline No & Utterances & Implicature & \multicolumn{2}{c}{$\begin{array}{c}\text { Type of } \\
\text { Implicature }\end{array}$} & Function \\
\cline { 3 - 5 } & & & GCI $\quad$ PCI & \\
1 & Golkar & Bersih, Golkar & Golkar is a party & V & Directive \\
\hline
\end{tabular}




\begin{tabular}{|c|c|c|c|c|c|}
\hline & $\begin{array}{l}\text { Menang Jokowi } \\
\text { Periode } \\
\text { Golkar is clean, Golkar } \\
\text { wins, Jokowi } 2 \text { Periodes }\end{array}$ & $\begin{array}{l}\text { that always } \\
\text { supports Jokowi to } \\
\text { become president } \\
\text { again in the second } \\
\text { period. }\end{array}$ & & & \\
\hline 2 & $\begin{array}{l}\text { Relawan GOJO } \\
\text { (Golkar-Jokowi) } \\
\text { Bersamamu Indonesia } \\
\text { Maju } \\
\text { GOJO Golkar-Jokowi } \\
\text { Volunteers, With you } \\
\text { Indonesia is advanced }\end{array}$ & $\begin{array}{l}\text { GOJO volunteers } \\
\text { are willing to help } \\
\text { Jokowi to advance } \\
\text { the Indonesian } \\
\text { country. }\end{array}$ & & V & Commissive \\
\hline 3 & $\begin{array}{l}\text { Jokowi itu Keren \& } \\
\text { Gaul 2019 Tetap Jokowi } \\
\text { Jokowi is Cool and Up } \\
\text { to date, } 2019 \text { Stay } \\
\text { Jokowi }\end{array}$ & $\begin{array}{l}\text { Mr. Jokowi is } \\
\text { extraordinary } \\
\text { president than usual } \\
\text { because of his } \\
\text { coolappearance. }\end{array}$ & & V & Directive \\
\hline 4 & $\begin{array}{l}\text { Kerja NyataVoor Rakyat } \\
\text { Mari Torang dukung } \\
\text { Jokowi Dua Periode } \\
\text { (Sejoli=Setuju Jokowi } \\
\text { Dua Kali) } \\
\text { Real Work for the } \\
\text { People, } \\
\text { Let's support Jokowi } \\
\text { Two Periods, (Sejoli = } \\
\text { Agree Jokowi Twice }\end{array}$ & $\begin{array}{l}\text { Manado people in } \\
\text { Siau Island support } \\
\text { and choose Jokowi } \\
\text { for the next period. }\end{array}$ & V & & Directive \\
\hline 5 & 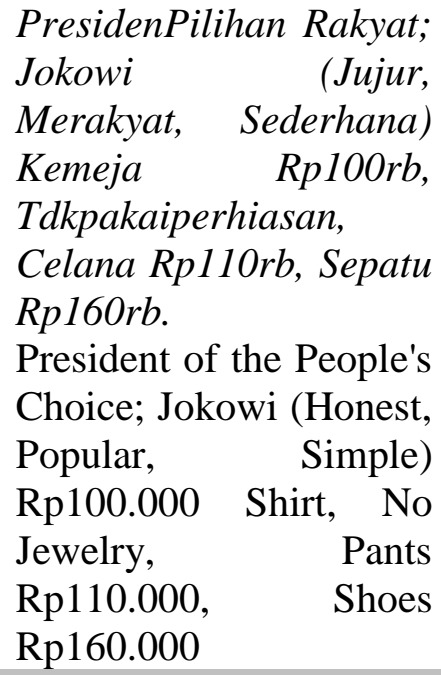 & $\begin{array}{l}\text { Pak Jokowi always } \\
\text { wears simple } \\
\text { clothes or the price } \\
\text { of his clothes is not } \\
\text { expensive }\end{array}$ & V & & Directive \\
\hline 6 & $\begin{array}{lr}\text { PDI } & \text { Perjuangan } \\
\text { Menang } & \text { Rakyat } \\
\text { Sejahtera } & \text { Presiden } \\
\text { Pilihan Kita } & \\
\text { PDI Perjuangan Wins, }\end{array}$ & $\begin{array}{l}\text { Choose } \\
\text { Jokowiagain as our } \\
\text { president to make } \\
\text { people prosperous. }\end{array}$ & V & & Directive \\
\hline
\end{tabular}


Vol.1, No.1 AUGUST 2018

\begin{tabular}{|c|c|c|c|c|c|}
\hline & $\begin{array}{l}\text { Prosperous People, } \\
\text { President of Our Choice }\end{array}$ & & & & \\
\hline 7 & $\begin{array}{l}\text { Suara Golkar Suara } \\
\text { Rakyat. Bersama Jokowi } \\
\text { kita berkarya untuk } \\
\text { bangsa } \\
\text { Voice of Golkar, Voice } \\
\text { of the People. Together } \\
\text { with Jokowi we work } \\
\text { for the nation }\end{array}$ & $\begin{array}{l}\text { Golkar is the party } \\
\text { representing } \\
\text { people's aspiration. }\end{array}$ & & V & Commissive \\
\hline 8 & $\begin{array}{l}\text { Prabowo-Sandi } \\
\text { TuntunlahJiwanya, } \\
\text { BangunlahBadannyaunt } \\
\text { uk Indonesia Raya } \\
\text { Prabowo-Sandi; Guide } \\
\text { His Soul, Build His } \\
\text { Body for Greater } \\
\text { Indonesia }\end{array}$ & $\begin{array}{l}\text { Prabowo\& Sandi } \\
\text { can build the nation } \\
\text { character into a } \\
\text { strong country. }\end{array}$ & & V & Directive \\
\hline 9 & $\begin{array}{l}\text { Yakin Mau Milih Yang } \\
\text { Lain? Emak2 dah } \\
\text { PadaSukaLoh } \\
\text { Prabowo-Sandi, Capres- } \\
\text { CawapresRepublik } \\
\text { Indonesia 2019-2024 } \\
\text { Are you sure you want } \\
\text { to choose another one? } \\
\text { Women are already in } \\
\text { love. } \\
\text { Prabowo-Sandi, } \\
\text { Presidential Candidates } \\
\text { and Vice-President of } \\
\text { the Republic of } \\
\text { Indonesia 2019-2024 }\end{array}$ & $\begin{array}{l}\text { Do not choose the } \\
\text { other. }\end{array}$ & & V & Directive \\
\hline 10 & $\begin{array}{l}2019 \text { Ganti Presiden } \\
\text { PAS (Prabowo-Sandi) } \\
\text { Calon Presiden dan } \\
\text { Wakil Presiden Republik } \\
\text { Indonesia } \\
2019 \text { Change President } \\
\text { PAS (Prabowo-Sandi) } \\
\text { Presidential Candidate } \\
\text { and Vice President of } \\
\text { the Republic of } \\
\text { Indonesia }\end{array}$ & $\begin{array}{l}\text { Choose Prabowo- } \\
\text { Sandi }\end{array}$ & V & & Directive \\
\hline
\end{tabular}

Surakarta English and Literature Journal 
Vol.1, No.1 AUGUST 2018

\begin{tabular}{llll}
\hline 11 Presiden RI 2019-2024 Not guarantee to be & $\mathrm{V}$ & Directive \\
Prabowo-Sandi PADI & safe, peace and & \\
(Pasti Aman Damai & beautiful & \\
Indah) & & \\
President of the & & \\
Republic of Indonesia & \\
2019-2024 Prabowo- & \\
Sandi PADI (Definitely & \\
Peaceful and Beautiful) & \\
\hline
\end{tabular}

Note:

GCI $=$ Generalized Conversational Implicature

PCI $=$ Particularized Conversational Implicature

According to the table above, there are total of 11 conversational implicatures(11 advertisements) occur in the presidential election campaign 2019 on online billboard advertisement. There are 5 conversational implicatures which belong to generalized implicature type and 6 particularized conversational implicatures which belong to particularizedimplicature. Then there are 2implicature having the commissive function and 9implicatures having directive function. These classified utterances are explained more clearly in data analysis.In this analysis, the writer only gives a description of flouting quality, quantity, relation and manner maxim, then a description of generalized and particularized conversational implicatures, then directive and commissive functions.

\section{ANALYSIS OF DATA}

\section{DATA 1}

GolkarBersih, GolkarMenang

Jokowi 2 Periode

Golkar is clean, Golkar wins, Jokowi 2 Periodes

Golkar party is clean, it wins. From the utterance, it could be drawn the meaning that the party supports Jokowi to be president for the second period. Unfortunately, the speaker did not give sufficient evidence as a clean party. How do readers believe that the party is clean? The statement 'Golkarbersih' is not enough just to be said only, but needs a proof. This statement flouts quality maxim which lacks of adequate evidence.

Based on this explanation, the implicature that arises is convincing the readers to choose and support the speaker.It has directive function (getting hearers to do what the speaker wants). The implicature belongs to generalized conversational implicature(GCI) because becausethere is no implied meaning or additional conveyed meaning with the speaker's utterances.

\section{DATA 2}

Presiden Pilihan Rakyat; Jokowi (Jujur, Merakyat, Sederhana) Kemeja Rp100rb, Tidakpakaiperhiasan, Celana Rp110rb, Sepatu Rp160rb.

President of the People's Choice; Jokowi (Honest, Popular, Simple) Rp100.000 Shirt, No Jewelry, Pants Rp110.000, Shoes Rp160.000

This billboard stated that Mr. Jokowi was the president of the People's Choice. The person is honest, populist \& simple by proving details price list of clothes, pants and shoes that 
Vol.1, No.1 AUGUST 2018

are not expensive and always worn by him. This statement flouts quantity maxim because the speaker gives too much information by proving details price list of his appearance uniforms.

Based on this explanation, the implicature that arises is convincing the readers to choose and support the speaker. It has directive function (getting hearers to do what the speaker wants). The implicature belongs to generalized conversational implicature (GCI) because there is no implied meaning or additional meaning with the speaker's utterances.

\section{DATA 3}

Jokowi itu Keren\& Gaul, 2019 Tetap Jokowi

Jokowi is Cool and Up to date, 2019 Stay Jokowi

This statement can be verified by looking at the picture that Mr. Jokowi is riding a big motorcycle and looks like a young boy. This statement flouts relation maxim because the speakerdid not give any relevance between his cool appearance and choosing Pak Jokowi to bethe next president.

Based on this explanation, the implicature that arises is persuading the readers to choose and support the speaker. It has directive function (getting hearers to do what the speaker wants). The implicature belongs to particularized conversational implicature (PCI) because there is implied meaning or additional meaning with the speaker's utterances.

\section{DATA 4}

Yakin Mau Milih Yang Lain?, Emak2 dah PadaSukaLoh

Prabowo-Sandi, Capres-CawapresRepublik Indonesia 2019-2024

(Are you sure you want to choose another one? Women are already in love. Prabowo-Sandi, Presidential Candidates and Vice-President of the Republic of Indonesia 2019-2024)

The speaker is asking for certainty not to be hesitated to choose Prabowo-Subianto. The handsome of the two presidential candidates usually attract the attention of women or mothers. This statement gives long utterances and produces ambiguousor obscurity meaning between the good looks of the presidential candidate and the election of Prabowo as a president? Therefore, this statement flouts manner maxim.

Based on this explanation, the implicature that arises is convincingreaders to choose and support the speaker. It has directive function (getting hearers to do what the speaker wants). The implicature belongs to particularized conversational implicature (PCI) because there is implied meaning or additional meaning with the speaker's utterances.

\section{DATA 5}

Relawan GOJO (Golkar-Jokowi)

Bersamamu Indonesia Maju

GOJO Golkar-Jokowi Volunteers, With you Indonesia is advanced

From the utterance, it could be drawn the meaning thatthe party supports Jokowi to be president for the second period. Unfortunately, the speaker did not give sufficient evidence on how this candidate can bring our country to be a developed country?. How do readers believe that the party is not lying? The statement 'Bersamamu Indonesia Maju' is not enough just to be said only, but needs a proof. This statement flouts quality maxim which lacks of adequate evidence.

\section{Surakarta English and Literature Journal}


On the other hand, the implicature that arises is promising the speaker that belongs to Golkar party if Pak Jokowi becomes president, Golkar party can help Pak Jokowito advance Indonesia country. It has commissive function (commitingthe speaker to some future action). The implicature belongs to particularized conversational implicature (PCI) because there is implied meaning or additional meaning with the speaker's utterances.

\section{CONCLUSION}

After discussing the result of analysis, the occurrence of conversational implicature is caused by the result of flouted maxim. Of 11 advertisements, the speakers mostly flout quality maxim in the presidential election campaign 2019 on online billboard advertisement as much as 6 advertisements on which they did not give evidence in uttering something to convince the readers. Then, the speakers flout quantity maxim in the presidential election campaign 2019 on online billboard advertisement as much as 3 advertisements. It means that not all political campaign use too much or too little information. The relevance and manner maxim get the same number, only found in one advertisement. Sometimes, the speakers use short and brief utterance in political campaign but they did not give any relevance. Conversely, they use long utterance and produces ambiguous meaning.

Referring to the types of conversational implicature, there are 5 generalized implicatures found and 6 particularized implicatures. Of 11 advertisements, there are 6 particularized implicatures which have additional meaning (implicit meaning) from an utterance. For instance, Relawan GOJO (Golkar-Jokowi) Bersamamu Indonesia Maju (GOJO Golkar-Jokowi Volunteers, With you Indonesia is advanced). Of the utterance, the golkar party is not only helping to campaign Jokowi. If Jokowi is elected, the golkar party wants its party to be chosen as a member of the Jokowi era ministry.

Based on the function, there are 5 types of function of implicature such as Assertive, Directive, Commissive, Expressive and Declaration.There are 9implicatures which have directive function involving Convincing, Inviting, andAsking. Then, there are 2 implicatures which have commissive function that is Promising. When the speaker commits himself to do something in the future (commissive function), he always does it by using PCI (Particularized Conversational Implicature). In short, he has implicit meaning or different meaning with the speaker's utterances. Meanwhile, the speaker can do directive function by GCI or PCI.

\section{REFERENCES}

Anindita, W.K., (2009). Code Switching And Code Mixing In Relation To Politeness Principle (Undergraduate Thesis, FakultasIlmuBudaya).

Cutting, Joan. (2013).Pragmatics and Discourse: A Resource Book for Students. Florence, KY, USA: Routledge.

Gunawan, I., (2013). Metodepenelitiankualitatif. Jakarta: BumiAksara

Handono, S., $\quad$ 2017.ImplikaturKampanyePolitikdalamKainRentang di RuangPublik. Aksara, 29(2), pp.253-266.

Herdi, R.N., (2012). RealisasiKesantunanBerbahasa Di Facebook: ResponMasyarakatTerkaitDenganIsuKenaikanHarga BBM (Doctoral dissertation, UniversitasMuhammadiyah Surakarta).

\section{Surakarta English and Literature Journal}


Vol.1, No.1 AUGUST 2018

Huda, M., (2013).Conversational Implicature Found in Dialogue of Euro Trip Movie. JurnalllmiahMahasiswa FIB, 3(1).

Nugraheni, Y., (2011). ImplikaturPercakapanTokohWanitadanTokohLaki-Lakidalam Film Harry Potter and The Goblet of Fire. Lensa: KajianKebahasaan, Kesusastraan, danBudaya, 1(2), pp.183-192.

Sudaryanto.(2015). Metodedan Aneka TeknikAnalisisBahasa. Yogyakarta: Sanata Dharma University Press.

(2014, June Friday). Retrieved February Thursday, 2019 from Detik News: https://news.detik.com/foto-news/d-2607591/baliho-jokowi-mejeng-di-jpo-otista

(2016, September Saturday). Retrieved February Thurday, 2019 from Gatra.com: https://www.gatra.com/rubrik/nasional/partai-politik/217095-pasang-baliho-bukanjaminan-golkar-usung-jokowi-pada-2019.

(2018, January Monday). Retrieved February Friday, 2019 from Kantor Berita Pemilu Melayani Indonesia Baru: http://www.kantorberitapemilu.com/read/2018/ 01/08/8659/Politisi-Golkar-Mulai-Sebar-Baliho-Jokowi-2-Periode.

(2018, April Monday). Retrieved February Saturday, 2019 from Warta Bromo: https://www.wartabromo.com/2018/04/30/komitmen-dukung-jokowi-balihorelawan-gojo-marak-di-pasuruan/

(2018, August Monday). Retieved February Wednesday, 2019 from Kumparan News: https://kumparan.com/@kumparannews/baliho-jokowi-itu-keren-and-gaulterpasang-di-jalanan-palembang-1535364286392669952

(2018, August Thursday). Retrieved February Friday, 2019 from Tribun Sitaro: http://manado.tribunnews.com/2018/08/16/baliho-jokowi-2-periode-beredar-disiau..

(2018, October Tuesday). Retrieved February Friday, 2019 from Merah Putih Berani Menginspirasi: https://merahputih.com/post/read/baliho-prabowo-sandi-dirusaktimses-ini-intimidasi-dan-preseden-buruk-bagi-pilpres-2019.

(2018, September Thursday). Retrieved February Wednesday, 2019 from Pilpres 2019: https://gorontalo.antaranews.com/berita/58922/sandiaga-resmikan-lamanwwwprabowo-sandicom.

(2019, March Sunday). Retrieved February Wednesday, 2019, from Tribun Lampung.co.id: http://lampung.tribunnews.com/2018/09/14/soal-baliho-jokowi-maruf-aminbawaslu-sesumbar-akan-panggil-herman-hn.

Surakarta English and Literature Journal 